\title{
Revolutionary Warfare? Assessing the Character of Competing Factions Within the Boko Haram Insurgency
}

Dr. Edward Stoddard

DIRPOLIS, Scuola Superiore Sant'Anna, Pisa, Italy and CEISR, University of Portsmouth, $U K$

Email: ed.stoddard@port.ac.uk - Twitter: @StoddardEd - ORCID: 0000-0001-5106-6315

\section{Biographical Note}

Dr. Ed Stoddard is a Marie Sklodowska-Curie Actions Fellow at the Scuola Superiore Sant'Anna, Pisa. He is also a Principal Lecturer in International Relations and Contemporary Security at the University of Portsmouth, UK (on research leave). At the Scuola Superiore Sant'Anna he is a member of the Emerging Research in International Security (ERIS) group and at Portsmouth a member of the Centre for European and International Studies Research (CEISR).

\section{Funding}

This work was supported by the EU Horizon 2020 Marie Sklodowska-Curie Actions under Grant 748164 - NWICWEP - DLV-748164.

\section{Disclosure Statement}

There are no conflicts of interest to report.

\section{Acknowledgements}

I would like to thank Prof. Tony Chafer, Prof. Francesco Strazzari and Dr. Claudia Leuders for helpful comments and discussions that assisted with sharpening the analysis here. Thanks also to Claudia for assistance with editorial aspects. All errors are my own. 


\title{
Revolutionary Warfare? Assessing the Character of Competing Factions Within the Boko Haram Insurgency
}

\author{
Dr Edward Stoddard \\ Marie Curie Research Fellow in Conflict Studies \\ Scuola Superiore Sant'Anna, Pisa and University of Portsmouth
}

\begin{abstract}
The respective politico-military characters of the competing factions within the Boko Haram insurgency have not received as much academic attention as other features of the Boko Haram phenomenon. This article uses the concept of 'revolutionary warfare' to examine and compare the two main factions. Traditionally applied to Marxist movements, this conceptualization is increasingly associated with violent Jihadist groups who combine a revolutionary ideology with a strategy based on winning popular support and a growing ability to militarily beat conventional forces. It argues that the 'Islamic State West Africa Province' faction has adopted a revolutionary warfare approach based on increasingly sophisticated semi-conventional warfare and a simultaneous drive to win popular support. The Jama'at Ahl as-Sunnah lid-Da'wah wa'l-Jihad faction, while equally revolutionary in its goals, appears for doctrinal reasons and due to pressure from the military, to be operating in contrast to key revolutionary warfare precepts.
\end{abstract}

\section{Introduction}

In 2016 the militant organisation colloquially referred to as 'Boko Haram (BH)' split into two main factions. ${ }^{1}$ One is known as the 'Islamic State West Africa Province' (ISWAP). This faction was led until recently (March 2019) by Abu Musab al Barnawi (reported to be Habib Yusuf, the son of BH founder Mohammed Yusuf) and is recognised by the 'Islamic State' as its affiliate in the region. The other main faction is led by Mohammed Yusuf's former deputy Abu Bakar al Shekau and often referred to by BH's original name Jama'at Ahl as-Sunnah lidDa'wah wa'l-Jihad ('the People Committed to the Prophet's Teaching and Jihad'), or JASDJ for short. While a good deal of excellent research has focused on the BH movement including on matters of ideology, ${ }^{3}$ history, ${ }^{4}$ the response of the Nigerian Government and others ${ }^{5}$ and the causes of the split, ${ }^{6}$ the question of how one should characterise the warfare conducted by BH factions has received less attention (for a exceptions see recent works by Mahmood and Ani, Omeni, and Törbjornsson and Jonsson). ${ }^{7}$ Furthermore, in terms of the wider literature on jihadism, the military character of the Boko Haram insurgency has received far less attention than other comparable groups - especially the 'Islamic State (IS). ${ }^{8}$

To assess the character of these two factions, this article employs the concept of 'revolutionary warfare'. While revolutionary warfare is historically most associated with Marxist movements, a growing literature has linked the concept to the study of violent jihadists. ${ }^{9}$ There is no one single definition of revolutionary warfare in the academic literature (either Marxist or Jihadist) although the practice is often described as 'Maoist' given the prominent role of Mao Tse-Tung in developing the concept. While 'revolutionary warfare' shares a lot with more standard guerrilla warfare, several interlinked features can be identified that make it more complex, and arguably more resilient, as a politico-military force. ${ }^{10}$ These include: 1) a revolutionary ideology that requires the seizure of territory in order to establish a new socio-political order; 2) a strategy for the development of popular support for a violent approach to achieving this objective, and; 3) a military strategy that sees a phased escalation from rural guerrilla actions to increasingly capable conventional military activity as a means to control territory. The article argues that the key difference between the factions surrounds the political question of popular support and the role this plays in military strategy. The al-Barnawi/ISWAP faction 
demonstrates a strategy of building popular support and a military approach that complements this approach. In doing so, it is extending a line of thinking that has existed for some time on the peripheries of the $\mathrm{BH}$ movement (notably in Ansaru) and is common to some other jihadists. ${ }^{11}$ In contrast, while the Shekau/JASJD faction is no less revolutionary in its goals (and thus certainly is a revolutionary group) for doctrinal reasons of its own choosing concerning the permissibility of targeting of civilians, it eschews the type of political approach to an insurgency that would be consistent with and necessary for a revolutionary warfare approach.

The article thus makes two main contributions. Empirically it uses an in depth mixed-methods case study of Boko Haram practice to present a new understanding of the differences between the characters of the two principal BH factions. Theoretically speaking it also validates findings on the parallels between previous revolutionary groups and contemporary jihadists by extending this beyond Islamic State and al Qaeda to another major 'affiliate' jihadist insurgency (or 'province' in IS's more hierarchical terminology). However, crucially, by finding that only one of the Boko Haram factions practices revolutionary warfare, it also highlights the considerable variation in revolutionary politico-military practice across jihadist groups (even amongst those in the same overall movement).

The article comprises five sections. The first briefly sets out the methodology employed highlighting the research design/data collection methods. The second section examines the notion of revolutionary warfare, setting out three features common to most approaches to revolutionary warfare. The third, fourth and fifth sections tackle the revolutionary ideology, approach towards the population and military strategy of both factions respectively.

\section{Assessing the 'Character' of Boko Haram Warfare: Methodology}

This article seeks to assess the character of warfare conducted by Boko Haram factions. What, however, is meant by an assessment of the 'character' of warfare? The analysis here takes inspiration from the recent literature on the changing character of warfare. ${ }^{12}$ Born of the Clausewitzian dictum that the nature of warfare remains constant but that its character changes through time and space, this literature seeks to assess continuity and change in the analysis of war $^{13}$. Central to this effort is a historical understanding of how previous examples of warfare help us comprehend contemporary cases. ${ }^{14}$ Simultaneously, however, this approach is sensitive to local drivers and the particularities of cases. Without attention to local specificities, there is of course a danger that "categorization rides roughshod over difference." 15 Indeed, notwithstanding the parallels between historical episodes of revolutionary warfare, there is a recognition in academic research that the successful diffusion of revolutionary warfare practice is due to the concept's malleable capacity for local adaptation. ${ }^{16}$ Therefore, differences between different applications of revolutionary warfare are, to a certain extent, to be expected.

The purpose of the paper, therefore, is not to prove that Boko Haram perfectly mirrors previous examples of revolutionary warfare (Maoist or otherwise), but rather to use the concept of revolutionary warfare to help assess and explain the differences in the character of military actions conducted by the different factions of the Boko Haram insurgency. As noted above, this article builds on a developing but rich seam of research that has drawn on parallels between previous waves of revolutionary insurgency and jihadist groups (especially al Qaeda and the 'Islamic State'). ${ }^{17}$ Research that applies this approach to the 'affiliates/provinces' of these organisations is currently lacking, however. 
Methodologically speaking, as Boko Haram leaders do not liberally quote Marxist strategists, this article proceeds through a close reading of their public statements and politico-military practice and comparing these to the wider historical practice of revolutionary warfare. Correspondingly, the article first establishes an ideal-typical framework based on key overlapping features of Marxist and jihadist revolutionary warfare thinking. This framework is then used to deductively assess the empirical character of the politico-military practice of ISWAP and JASDJ. As with any deductive study, effort must be placed into both assessing where empirical reality fits the framework and, crucially, where it does not (without the latter the risk of confirmation bias is high). Finally, as Abu Musab al Barnawi was overthrown during the writing of this article, the findings of the paper are limited to the time period up until the end of his tenure as leader (see endnote two).

\section{Data Collection}

Researching the Boko Haram movement is challenging for several reasons. Firstly, and most significantly, accessing the far north-east of Nigeria is difficult for security reasons. ${ }^{18}$ Secondly, there are few single sources of data that give a comprehensive picture of BH's actions. Rather research on Boko Haram benefits from an eclectic approach that triangulates between different data sources. This article employs a mixed methods approach drawing on data from six sources: 1) Texts of Boko Haram members' speeches and other public utterances - many collated in the excellent "Boko Haram Reader"19; 2) Video/photo evidence from Boko Haram productions collected online; 3) Quantitative data from the Armed Conflict Location and Event Database (ACLED) that records violent incidents in Nigeria by actor (including the two $\mathrm{BH}$ factions and the government ${ }^{20}$ ); 4) analytical blog pieces on $\mathrm{BH}$ written by analysts using open source intelligence/investigation methods; 5) international and Nigerian journalistic sources, and; 6) reports from organisations with access to conflict zones. These observations are also informed by conversations the author had with security officials on a research trip to Abuja, Nigeria in July 2016 (however these discussions do not feature directly in this analysis as most of the developments here have taken place since). Materials released by Boko Haram must, of course, be treated with caution as they are propaganda. They do nevertheless present important evidence on how $\mathrm{BH}$ factions want to be seen, and critical reading of these documents can tell us a lot about BH thinking. Similarly, ISWAP or JASDJ videos that depict battles cannot be taken as evidence of all BH fighting (they largely of course only present battles they win) but they do give important insights into capabilities, tactics, weapons usage and other features that are useful for the analysis here.

\section{Three Key Dimensions of Revolutionary Warfare}

'Revolutionary warfare' describes a form of military practice particularly associated with Marxist rebellions during the Cold War. ${ }^{21}$ It refers to a set of practices that are "designed to use guerrilla warfare combined with political action to further an ideology in place of the incumbent government". ${ }^{22}$ While there are numerous examples of 'revolutionary warfare' in history, the ideas of revolutionary leaders Mao Tse-Tung and Nguyen Giap are normally afforded a prominent position in the literature given the role they played in developing the practice. ${ }^{23}$ Before Mao, the dominant theory of successful revolution was the MarxistLeninist theory of (urban) proletariat revolution. ${ }^{24}$ After seeing Chinese communists try and fail at this urban-centric approach, Mao developed an alternative that combined revolutionary theory with guerrilla insurgency. ${ }^{25}$ After Mao, proponents of revolutionary warfare saw that insurgent action could be instrumental in both winning popular support and overthrowing regimes. 
A number of scholars have drawn attention to the links between jihadist military practice and previous examples of revolutionary warfare. A decade ago, Mackinlay used the concept of 'post-Maoism' to capture the character of this globalised network of insurgents, terrorists, and supporters. More recently Whiteside has analysed the 'Islamic State's' conduct of revolutionary warfare and drawn parallels with the actions of Vietnamese revolutionaries. ${ }^{26}$ Likewise, Hecker has highlighted the "passerelles strategiques" ('strategic bridges') between jihadists and Marxist-Leninist and Maoist revolutionary thinkers such as Carlos Marighella and Amilcar Cabral. ${ }^{27}$ Similarly, both Kalyvas and Walt have noted the similarities between ISIS and previous Marxist revolutionaries, with Kalyvas describing ISIS as a "revolutionary group" and Walt taking a more realist lens and describing ISIS as a "revolutionary state."28 More recently, Kalyvas has extended his argument about IS to jihadist rebel groups more generally. ${ }^{29}$ Others have explored the ideas of Jihadist 'strategists' of revolutionary warfare who draw on Maoist military ideas, principally Abu 'Ubeid Al-Qurashi, Abu Mu'sab al-Suri, and $\mathrm{Abu}$ Bakr Naji ${ }^{30}$ and Abd Al-'Azizal-Muqrin ${ }^{31}$. As a number of scholars have demonstrated, jihadists seem to have learned from and adopted core ideas from Marxist thinkers ${ }^{32}$. Somewhat surprising in the studies of these 'jihadist scholars', is their reliance on non-Muslim sources of strategic thinking (such as Paul Kennedy, Thomas Hammes and Robert Taber), but their work ultimately relies on Marxist theorists of revolutionary warfare, notably Mao, Giap, and Guevara. As Thurston notes, in an interview for ISIS's al Naba' magazine alBarnawi appears to be aware of ISIS's stages of establishing a Caliphate (see below) which builds on Naji's work. ${ }^{33}$ It is highly likely that the leaders of Boko Haram are aware of these works and ideas given how well-known they are in jihadi circles.

Most discussions of revolutionary warfare in the literature tend to focus on three key intersecting features of the overall strategy, each mutually supportive of the others. They are:

1) Revolutionary aims born of a radical ideology that promotes territorial control to enact a reorganization of the socio-political order. Indeed, scholars often highlight the politically radical nature of insurgents' goals in the discussion of the concept of revolutionary warfare. Condit describes revolutionary warfare as "a violent, illegal, domestic challenge to a government" that "involves some degree of internal systemic change as a revolutionary goal and the use of illegal force as a means." 34 As Kalyvas notes revolutionary rebels aim not just to "achieve power" but rather to "to transform society in a deep and radical way, by profoundly rearranging social and political relations." ${ }^{35}$ Al-Qaeda strategist of warfare al-Qurashi similarly defined revolution as "a comprehensive and fundamental change to the political order, social structure, economic ownership, and the standing social order." ${ }^{36}$ Revolutionary warfare is thus deeply ideological in nature with ideology driving both the end goal and, often, insurgent actions. As will be seen below, both Boko Haram factions advocate a complete revolutionary transformation of the political order in Nigeria and beyond.

2) The development of popular support. A second crucial dimension of revolutionary warfare is its mobilization component and the question of building popular support (or at the least tacit popular consent). ${ }^{37}$ Revolutionary insurgents require support both for their overall objective (revolutionary change) and for the approach to achieving it (escalating insurgency). The support of the population was particularly important to Mao. ${ }^{38} \mathrm{He}$ argued in a famous analogy that the people should be considered like 'water' and the Communist forces like 'fish' indicating that for survival, his forces needed, at the least, the implicit support of the rural population. ${ }^{39}$ Correspondingly he stressed the need for "a unity of spirit that should exist between the troops and local inhabitants." ${ }^{40}$ Crucial to this were two factors: firstly, winning 
over the local population by treating them well and 'protecting' them from predatory militias, warlords and the state; and, secondly, by then using the goodwill generated to attract people to the communist cause. The question of popular support thus serves to make life easier for the insurgents and harder for the security forces by offering access to material support (e.g., food or fuel), intelligence (and denying this to the state), by providing recruits for the cause, and the possibility of quick momentum if/when the government falls.

This sentiment is widely shared by major jihadist theorists of warfare. Payne notes that many jihadist strategists advocate an approach that echoes Guevara's 'focoist' insurgency model. ${ }^{41}$ Guevara was inspired by Mao's theories but argued that violence itself could play a key role in developing support through polarization. ${ }^{42}$ The difference between Maoist and Focoist approaches is a difference of degree rather than kind, and there is no fundamental theoretical tension between them at least in terms of the need to win support ${ }^{43}$ (although practicallyspeaking there can be if the violence is so extreme that it alienates target audiences - a point jihadists have also stressed). Jihadists, in general, have probably been closer to this focoist line of argumentation in their desire for immediate action, but developing popular support is nevertheless a preoccupation of strategists of violent jihad. In his book the Management of Savagery, Naji discusses the importance of polarising society (through violence) into those for and against the jihadists, but stresses also the need to "attract the sympathy" of those who are neutral and "make it [the group of neutrals] hope for the victory of the people of the faith [the jihadists] especially since this group has a decisive role in the latter stages of the present battle". ${ }^{44} \mathrm{He}$ talks also of winning over tribes by co-opting their leaders (with money if necessary) and encouraging ordinary tribe members to align with the jihadists through interaction with the jihadists. ${ }^{45} \mathrm{He}$ also suggests "forgiving" those who are on the side of the government when there is no cost in doing so and when such actions might win them over to the jihadists. ${ }^{46}$ As will be seen below, ISWAP has put a good deal of effort into attracting wider members of the civilian Muslim population to its cause, including those who live in government controlled areas or engage with the Nigerian government. The Shekau faction, by contrast, has a more hard-line view on civilians and regularly uses extreme violence against members of the Muslim population.

The seeking of popular support amongst a target population is not a sign of general moderation or proclivity against violence however. Mao was reported to have said that "leniency towards the enemy is a crime against the revolution". ${ }^{47}$ The same is true for IS and its precursor organisations which have railed against Arab governments and other denominations, especially the Shia. ${ }^{48}$ Indeed, the use of extreme violence and developing popular support can be linked. Revolutionaries (Jihadist and Marxist) have highlighted the 'threat' that enemies present and portrayed themselves as defending their target audiences from their 'predations' (even if they knowingly induce attacks against 'their' population). As will be discussed below, competing for doctrinal definitions of who is to be protected and who is an enemy to be killed within 'Boko Haram' movement has had a pronounced effect on the character of insurgent warfare.

3) Enactment of a phased military strategy that sees an evolution from guerrilla insurgency to conventional conflict in order to gradually seize territorial control and create the space required to enact the social reforms needed to win popular support. ${ }^{49}$ Seizing and controlling territory is extremely difficult to do against a conventional army without at least semiconventional tactics. Mao recognized this and his approach to 'protracted war' saw an evolution across three phases from 'strategic defence' that sees forces embedding themselves in the local population and conducting guerrilla actions designed to cement that objective, to 'strategic stalemate' where insurgent forces step up their military actions including raids on 
outposts, attacks on supply lines and finally to 'strategic counter offensive' which sees "the enemy's destruction by orthodox military operations which do not necessarily deny guerrilla operations but place them in a subsidiary role". ${ }^{50}$

Numerous jihadist strategists offer a similar model of revolutionary warfare building on 'stages' of warfare. In its first edition of its Dabiq magazine, the 'Islamic State' advanced a five stage model that runs from withdrawal or emigration (hijrah) to an area of limited state power, the establishment of a jihadist organisation, the destabilization of regimes through creation of a state of 'savagery', the consolidation of territorial control and finally the declaration of a 'caliphate'. ${ }^{1}$ This framework is itself based on Naji's model in The Management of Savagery that outlines a number of key stages: 1) a 'stage of vexation and exhaustion that is designed to exhaust government forces and force them from a given region; ${ }^{52}$ 2) a 'stage of the administration of savagery' where the jihadist organisation will provide public services, win the hearts and minds of the population and put pressure on government forces denying them the ability to operate near the newly controlled region; ${ }^{53}$ and finally, 3 ) the "stage of the power of establishment' (referring to the declaration of a Caliphate - although Naji doesn't give many details on this final stage). ${ }^{54}$ Another important jihadist strategist al-Muqrin (former leader of al Qaeda in the Arabian Peninsula) offers a three-stage model that almost perfectly mirrors Mao's approach, only differing in that it does not envisage the establishment of a regular army but rather the continued operations of loosely-organised mujahedeen. ${ }^{55}$ Of course, in practice, no war progresses so linearly. Indeed, the Vietnamese general Vo Nguyen Giap explicitly promoted the non-linear character of this evolution from strategic defence to stalemate to offence advocating that forces moved back and forth through these stages depending on the context. ${ }^{56}$ Nevertheless, the broad outlines of these staged models highlight (at least in its ideal-typical form) the evolution from guerrilla insurgency to more sophisticated semi-conventional/conventional operations in revolutionary warfare.

\section{A Revolutionary Movement: Revolutionary Ideas in Boko Haram Thought}

Having outlined three key intersecting features of revolutionary warfare, the remaining sections apply them to ISWAP and JASDJ. The purpose of this first section is to assess the question of revolutionary ideology. The objective here is not to give a fully comprehensive discussion of $\mathrm{BH}$ 's ideology but rather to establish the revolutionary content of the movement's ideas and discuss important factional differences (continued in the next section). Both the ISWAP and JASDJ share a common radical genealogy. However, the Shekau faction has a much stricter application of two jihadist-salafist concepts 'loyalty and disavowal' (al-wala wa-l-bara) and 'excommunication' (takfir), that marks a key distinction between the two. ${ }^{57}$

In some ways, the Boko Haram movement is not entirely unique in Nigeria. Indeed, the wider movement is just one of many revivalist (tajid) groups that advocate a return to an idealised, religiously purer time devoid of corrupting foreign influences. ${ }^{58}$ They, like other Salafists, seek a return to the practices of the 'pious predecessors' (salaf) - the first generations of Muslims thought to represent the closest example to the practice of the Prophet Mohammed. For a good deal of his time as a preacher, Yusuf was what Wiktorowicz has described as a "politicosalafist" 59 seeking to work alongside the state to encourage and cajole change in line with his salafist worldview. ${ }^{60}$ Nevertheless, having faced a crackdown by state forces on the $\mathrm{BH}$ movement that authorities deemed was becoming too radical, by the time of his death at the hands of the Nigerian forces in 2009, Yusuf had certainly come to be an advocate for a revolutionary jihad. Both factions continue this tradition. 
In this vision, $\mathrm{BH}$ leaders have drawn on both local Nigerian tajid traditions and adherence to global jihadist-salafism. Members take inspiration from the historical example of Usman dan Fodio who launched a jihad to establish the Sokoto Caliphate (covering most of what is today northern and central Nigeria, as well as parts of neighbouring states) from $1804 .{ }^{61}$ Kassim notes however that "Boko Haram is the first Islamic group in northern Nigeria to construct an ethical framework for the theological legitimization and meta-justification for divinely sanctioned jihad using the theologico-juridico resources of the global Jihadi-Salafism and the Islamic traditions of Uthman Dan Fodio". ${ }^{62}$ BH's thought is also certainly imbued with revolutionary ideas shared with other jihadist groups. This can be seen in the works of Yusuf, who was influenced by jihadist thinkers such as Abu Muhammad al-Maqdisi and Abu Basi al-Tartusi. ${ }^{63}$ We see in Yusuf's world view (and that of his successors) not just a vision for a change to the political order, but rather a total rejection of the Nigerian state (at least in his latter proclamations). ${ }^{64}$ For jihadi-salafis, living under non-Muslim leaders is unacceptable and Muslim leaders who do not rule in line with their jihadist-salafist interpretation are taghut (tyrants) and apostates. It is considered legitimate (indeed obligatory) to both claim takfir (excommunication) against them and seek to remove them from power. ${ }^{65}$ After his death in 2009, new leaders took up Yusuf's mantle as leader of Boko Haram and continued in earnest his view that the Nigerian state is a conspiracy of Christians and taghut that needed to be expelled from northern Nigeria and a new 'Islamic' state be implemented in its place. ${ }^{66}$ Despite the importance of the Nigerian context in the rise of 'Boko Haram', it should be noted that both factions operate transnationally in the region and have transnational links to other jihadist groups, even if their roots and the vast majority of their actions are located in Nigeria. Neither group respects international borders or the regimes in neighbouring countries (see below) and it has attacked them repeatedly, however the historic origins of the insurgency and most of its actions have been centred in Nigeria.

Both Yusuf and his successor, Abu Bakar al Shekau have stressed the notion of al-wala wa-lbara often translated as 'loyalty and disavowal. ${ }^{67}$ In part, this is directed against the leaders of Nigeria and states in the region. In an address to "African leaders" in 2015, Shekau stated "we make disavowal from you and your path. We disbelieve in you and your polytheist constitutions and nationalistic parliaments. And between us and you is enmity, hatred forever until you believe in the oneness of God" ${ }^{68}$ Yusuf and Shekau used this notion, to claim takfir (excommunication punishable by death) on numerous groups especially those working directly for the Nigerian state, but also religious scholars who do not disavow the Nigerian state. In Shekau's case, he extends it (radically and controversially even within jihadist thinking) in a highly exclusivist fashion to all other Muslims who do not embrace and actively support his group. ${ }^{69}$ Here, however, we see a big difference between the al-Barnawi ISWAP and Shekau's factions that has a considerable bearing on the question of winning popular support - a crucial part of a revolutionary warfare approach.

\section{The Population Dimension: Takfirism, Popular Support and Revolutionary Warfare}

The starkest difference between the revolutionary politico-military character of the two Boko Haram factions lies in their approach to the wider Muslim population. Here we see different readings of al-wala wa-l-bara and takfir blending with different political strategies. Consistent with a broader revolutionary warfare approach, the ISWAP faction, like the earlier breakaway factions of BH and the jihadist strategists such as Naji and al-Muqrin described above, employs a more limited view of takfir and engages in political strategies to appeal to and win popular support among the Muslim population. It is important to note that these are two interlinked but distinct choices for ISWAP in that it would be possible to hold a more restrained view of takfir 
but to otherwise largely ignore the population. Rather, ISWAP has a more forgiving attitude in terms of takfir and tries to engage the population to its cause. By contrast, the Shekau faction adopts a very strict view of al-wala wa-l-bara and an expansive view of takfir that makes attacks against the civilian population necessary from their point of view. JASDJ seeks to achieve the compliance of the Muslim population less through a politics of co-optation or legitimacy-building than extreme violence and coercion.

\section{JASDJ and the Civilian Population}

The Shekau faction's very hard-line positions on al-wala wa-l-bara and takfir are justified by Shekau and others in terms of doctrine, but they have also hardened over time. This is especially the case since the summer of 2013 and the establishment of the Civilian Joint Task Force (CJTF). ${ }^{70}$ The CJTF ('yan goro' in Hausa) is a government-supported civilian militia that operates across the most affected Nigerian states. After it had helped expel Boko Haram fighters from Maiduguri, the capital of Borno, and other towns, Boko Haram vowed revenge against the CJTF (which its spokesman at the time Abu Zinnira defined expansively as the "Youth of Borno and Yobe States"). ${ }^{71}$ Its attacks against Muslim civilians soon started in earnest. Data analysed by Campbell and Harwood (2018) shows that civilian deaths spiked around 5-6,000 per year in 2014 and 2015 around the time Boko Haram started to clearly target Muslim communities. This shift in targeting is evidenced by attacks on religious sites. As a proportion of attacks, strikes on mosques (relative to churches) started to increase in 2014 and by 2015 mosques made up the majority of religious attack sites for Boko Haram. ${ }^{72}$ In its reaction to civilian militia support for the Nigerian state, Shekau essentially claimed takfir against the wider Muslim population and adopted a position that rejects a strategy to win the support of the wider population.

An interesting comparison on this issue (and a sign of pre-split tensions within Boko Haram) are speeches released by al-Barnawi and Shekau respectively following an attack on the town of Baga in 2015 that killed many civilians. Al Barnawi (JASDJ spokesperson at the time) tried to suggest that Boko Haram had only fought the CJTF, and even then that most of them had fled. ${ }^{73}$ On the point of the CJTF he stressed "we send them [the CJTF] this message: those that fought us or did not fight us, but who come to us in repentance will be forgiven and given safety and security, because we are an Umma [community] whose morals refuse to initiate harm against those that do not harm us" "74. Discussing the same attack, Shekau, by contrast, stated the following: "We JASDJ are those that fought the people of Baga, killing them thoroughly. Just as He commanded us in his book. We will not stop ever". ${ }^{75}$ In the same pronouncement, al Barnawi proclaimed that "if you are not with us then at least do not be against us." This contrasts significantly with Shekau's very strict view on both al-wala wa-lbara and takfir ${ }^{76}$ Indeed, it is this strict view of al-wala wa-l-bara and takfir that explains a large part of the seeming contradiction between some of Shekau's wider statements framing him and Boko Haram as defenders of Islam and Muslims and his attacks on civilians (although he appears to present himself as a defender of the former more than the latter). ${ }^{77}$ In practice he has come to define who is a Muslim (and thus who is a member of the Islamic community) very narrowly, with violence meted out to those who do not meet his criterion.

\section{ISWAP's More Population-Centric Approach}

There has long been opposition to Shekau's stance on the peripheries of Boko Haram. Indeed, this lies behind the biggest pre-2016 split within BH when the splinter movement Ansaru broke away in 2012. Just as ISWAP would come to do, following Boko Haram's attacks in Kano in 
2013 that killed over 60 people, Ansaru felt it was necessary to distance themselves from the rest of BH. They stressed their "dissociation from targeting the masses of Muslims who have spoken the two declarations of faith". ${ }^{78}$ They argued in contrast that the Muslim masses should "form a line around your Mujahidin brothers so this will be a popular revolt against the corrupt rulers" [emphasis added]. ${ }^{79}$ Ansaru clearly desired a popular-supporting uprising against the Nigerian state, but it is not clear if they saw this as in 'putschist' or protracted revolutionary warfare terms. While al-Barnawi criticised Ansaru in a book he published in $2018^{80}$ there is some considerable overlap between the Ansaru and ISWAP positions towards the population. ${ }^{81}$ In the case of BH's attacks in Baga in 2015 (mentioned above), al-Barnawi was at pains to stress that in its wider operations $\mathrm{BH}$ was acting on behalf of the wider population noting "[h]ow is it that we fight Muslims if we fight for their cause?"82 [emphasis added]. Ansaru used very similarly messaging in their denunciation of the attacks on Kano stressing that "the reality is that your salvation from the labyrinth and loss, and poverty and injustice, is the reason for the struggle" [emphasis added $]^{83}$.

Post-split, al-Barnawi and the ISWAP faction seems to be continuing this line of thought. For example, in his 2018 book refuting Shekau's practices, al-Barnawi suggests that ISWAP does not target Muslims living in government-controlled areas and argues that refraining from physically joining Boko Haram does not invalidate someone as a Muslim in his eyes. Furthermore, he notes that people would face many practical difficulties in making such a move - not least the presence of the military. ${ }^{84}$ As part of their ongoing dispute, Al-Barnawi argues that Shekau was not able to successfully administer territories under his control during the 2014-15 'caliphate' and suggested that he "sow[ed] corruption and ruined the cultivation and animals" in the areas he administered (this reference to 'cultivation and animals' may or may not be literal, but it highlights al-Barnawi's position on Shekau's inability to manage territory ${ }^{85}$. We cannot accept al-Barnawi's comments as an authoritative verdict on Shekau's capacity to administer the territory of course because he is not a neutral party in these matters. However, al-Barnawi's critique of Shekau's control of territory based on the premise that he could not and didn't want to protect and provide for the population does highlight his own views on how territory should be administered and how he feels Boko Haram should engage with the population (or at the very least how he wants his group to be seen). Being seen to 'protect' the population and 'providing' for them is, as we have seen, in line with revolutionary warfare thinking and in line with other jihadist thinkers that advocate such an approach.

\section{Building Support on the Ground?}

Crucially, beyond messaging, ISWAP appears to be melding these views into strategic practice. Reuters journalists Paul Carsten and Ahmed Kingimi spoke to herders who operate in ISWAP controlled territory who noted that "if you are a herder, driver or trader, they [ISWAP] won't touch you - just follow their rules and regulations governing the territory" adding that "they don't touch civilians, just security personnel". ${ }^{86}$ Deutsche Welle reported one local resident of Damboa in Borno state saying that in his area ISWAP conducts roadblocks like the Nigerian Army, taxes civilians in return for 'protection' but does not kill civilians. ${ }^{87}$ There are reports of well-digging and the use of 'soft loans' (a tactic used by Yusuf in Maiduguri prior to 2009) as a means of winning over rural populations. ${ }^{88}$ Carsten and Kingimi argue that there is a perception that ISWAP can protect local populations from the Shekau faction that the group has a well-connected network of informants. ${ }^{89}$ Mahmood \& Ani suggest that ISWAP has used similar narratives in Chad, claiming that it protects civilians from local officials and security forces who are accused of extorting the civilian population. ${ }^{90}$ Proselytization videos produced by ISWAP have reportedly been distributed in Internally Displaced Person (IDP) camps in an 
effort to get displaced persons to return to their villages. ${ }^{91}$ Similarly, Carsten and Kingimi argue that al Barnawi has sent operatives into IDP camps to encourage people to return to areas they control. If this is the case, it would be in stark contrast to the practice of the Shekau faction with regard to IDP camps which have been regularly attacked (see below). Similarly, when ISWAP militants stormed the town of Baga at the very end of December 2018, the BBC reported that they led prayers in the mosques the next day telling local residents that they would not be targeted and that they were free to leave the town if they wanted to. ${ }^{92}$ France 24 has reported that ISWAP has embarked on an aggressive recruitment campaign over the latter half of 2018 with imams loyal to the group presenting ISWAP as a "credible and legitimate" alternative to the government. ${ }^{93}$

In line with the previous experience of revolutionary warfare proponents elsewhere, these actions mean that ISWAP can access the local population for support (in terms of food, supplies, and intelligence), even if local populations are unlikely to have much say over whether they acquiesce or not. ${ }^{94}$ This is also seen in the economic approach of ISWAP which appears to be engaging with local economies rather than the extortion and destruction of economic goods as often practiced by Shekau's group. ${ }^{95}$ ISWAP is thought to be engaged in various forms of economic activity such as taxing trades such as pepper and fishing in return for protection. ${ }^{96}$ Salkida reports that ISWAP has taken control of key markets in northern Borno and seeks to provide an economically more conducive environment for local citizens than the military can. ${ }^{97}$ This structures remain flexible and informal and thus cannot be targeted by the Nigerian military as they can be re-established as soon as the soldiers are gone. Again participation for civilians is not necessarily voluntary, and there are reports of traders who have not paid protection money to ISWAP being killed. ${ }^{98}$ Furthermore, interaction with the group puts civilians and traders in an unenviable position when they then come into contact with the military who may then associate them as supporters of ISWAP. ${ }^{99}$ Nevertheless, as Kilcullen has discussed in the context of 'competitive control' strategies in Afghanistan, if prior interaction with ISWAP marks civilians out as collaborators in the eyes of the military, putting civilians in this position may have benefits for ISWAP as it pulls locals into the militants' orbit and gives them a stake in ISWAP's success. ${ }^{100}$ They may have little choice to collaborate, but once they do they may well be locked in to that collaboration through fear of retribution.

Propaganda material released by Islamic State on behalf of ISWAP shows an effort to highlight that the group is actively working to protect and support the population under its areas of (relative) 'control.' The video 'Tribulations and Blessings' (July 2018) has a scene that focused on agricultural production in areas that claimed to be under ISWAP influence ${ }^{101}$. It suggests that the agriculture in the Lake Chad region is performing better than before the following support from ISWAP against the Nigerian military (who are accused of taking food for other parts of Nigeria). A farmer notes that they have had no problems from Islamic State soldiers and claims that soldiers have protected them. He goes on to refute suggestions that ISWAP have been killing farmers. A similar message comes from another farmer who also states that it is a "lie" that "the Mujahideen" kills Muslims and that it is equally a lie that they steal. This footage is followed by a montage of large quantities of fish being landed and a walk through an open market. This highlights ISWAP's twin desire to be not only seen as helping 'improve' the situation for ordinary Muslims but that they are also protecting them from a conspiracy to redirect food to other (non-Muslim) parts of Nigeria. Again, this is propaganda and may not be a realistic image of life in the areas where ISWAP has influence (and may equally exaggerate their influence), but it nevertheless highlights that they are trying to present themselves as supporters of the population. 
Similarly, while the details are somewhat unclear, ISWAP members are thought to have released a number of kidnapped Muslim girls in 2018 (initially taken by ISWAP) from the town of Dapchi. Some militants are thought to have claimed that they wouldn't have taken them had they known they were Muslim and the government claims that no ransom was paid ${ }^{102}$. While it is impossible to know if a ransom was paid or not (and while the group did not release one of the girls - Leah Sharibu - who refused to renounce her Christianity), the move highlights their attempts to be seen in a positive light by the population. Video reporting to be of the release certainly shows a jubilant population surrounding purported ISWAP fighters ${ }^{103}$. If a ransom was paid, it is likely a win-win for the group of course in that they both get access to finance and a reputational boost.

This approach appears to be having a positive effect in terms of recruitment to the group. The International Crisis Group has suggested that ISWAP may have as many as 3500-5000 members (overshadowing JASDJ which is thought to have between 1500-2000) ${ }^{104}$. The Maiduguri-based academic and journalist Chitra Nagarajan recently spent time discussing ISWAP recruitment with local communities in Yobe state noting that military closures of markets (in an effort to restrict ISWAP's ability to control them) was having a detrimental effect and driving some towards ISWAP's message. ${ }^{105}$ Similarly, journalist Obi Anyadike spoke with men who has left recently (re-captured) Baga noting how they regularly receive calls from friends inviting them to return to Baga where, they are told, provided they pay their taxes ISWAP lets them go about their business. All told, he concludes that ISWAP presents a serious political as well as military challenge. ${ }^{106}$ These recruitment efforts stimulated the Multinational Joint Task Force to put out a communique in June 2019 warning of a ISWAP recruitment drive over the summer of $2019^{107}$.

It is very important not to paint a rosy picture of ISWAP through the comparison with JASDJ. Firstly, the al-Barnawi's faction is not necessarily less extreme than Shekau's in terms of the violence it conducts - they are just more lenient with the Muslim population. Another note for caution is the execution of one of ISWAP's top commanders and most 'population-centric' leaders, Mamman Nur, by other ISWAP members in mid-2018. While the details surrounding his death are unclear, this does not appear to have triggered a major change in ISWAP's position towards civilians. Finally, it is not possible from the evidence used here to show whether this strategy is working on the ground or to assess whether the civilian population makes a distinction between ISWAP and JASDJ. ${ }^{108}$ Overall, however, the al-Barnawi faction appears to have invested considerable energy into demonstrating that they do not want to be seen as a threat but rather as protectors and providers. In contrast to Shekau, this line of thinking appears to mirror more closely the actions of previous (Marxist and Jihadist) proponents of revolutionary warfare who have advocated winning over populations as part of their military strategy.

\section{Factional Differences in Post-split Military Activities and Revolutionary Warfare}

This section assesses the different military positions adopted by the two factions since the split in 2016 and how these relate to the notion of revolutionary warfare. It examines how the Shekau faction shows a continuity of its civilian targeting tactics with pre-split Boko Haram. ${ }^{109}$ While an effective, albeit brutal, use of guerrilla warfare, this approach continues to push the group away from a more politically-minded revolutionary warfare strategy. By contrast, the ISWAP faction has focused its violent activity largely on the Nigerian military and, having undergone a period of relative withdrawal and 'strategic defence' until the summer of 2018, now appears resurgent with its campaign characterised by 'strategic stalemate' in Maoist parlance or 
somewhere between the 'vexation and exhaustion' and 'management of savagery' phases as outlined by al-Naji.

\section{Continuity: JASDJ's Continuation of Raids on Civilian Sites and the Military}

By the time of the split in $2016 \mathrm{BH}$ had already demonstrated a capacity for a range of military activities from terrorism and assassination to semi-conventional conflict and territorial acquisition. The group demonstrated (as ISWAP would later - see below) the capacity to move from strategic defence to strategic stalemate, and even strategic offence for a period when the group captured territory in 2014. The attack on the town of Baga in January 2015 (mentioned above) highlights the upper end of this capability. Baga is significant, not just for having been attacked several times, but also for being the former headquarters of the Multinational Joint Task Force (MNJTF - comprised of Chadian, Nigerien, Nigerian and Cameroonian forces). Burns highlights how BH conducted a sustained attack on the town with an assault force supported by security and support groups. ${ }^{110} \mathrm{BH}$ fighters first attacked the MNJTF base, briefly being repelled before later returning and taking the base forcing the Nigerian defenders to retreat. They then proceeded to attack Baga itself before moving on to nearby Doron Baga razing much of the town and killing civilians. ${ }^{111}$ It was a month before the Nigerian Army recaptured the towns and $\mathrm{BH}$ fighters were forced to flee. ${ }^{112}$

This example is illustrative of a broader trend in BH/JASDJ violence: even as BH increased its military capabilities to the point where it could take on the Nigerian military (strategic stalemate in terms of revolutionary warfare theory), it maintained its focus on targeting Muslim civilians. Indeed, coming at the height of BH's pre-split power, the attack on Baga is thought to have been one of the most deadly attacks in Boko Haram history for civilians. ${ }^{113}$ In the six months leading up to Shekau's declaration of the caliphate in August 2014 (a time of high activity against state forces) JASDJ launched 141 attacks on civilians and engaged in 73 battles against state forces ${ }^{114}$. That is a ratio of almost two (1.93:1) attacks on civilians for every engagement with the military (for a comparison between ISWAP and JASDJ targeting of civilians see below). ${ }^{115}$ This continued after Boko Haram had started to lose the territory it had controlled in 2014/2015. Boko Haram's assault on the town of Dalori on the 30th January 2016 presents one example of many. ${ }^{116}$ Fighters attacked the town in vehicles and on foot, shooting civilians and then burning swathes of the town. The attack was reportedly supported by three female suicide bombers who exploded their bombs among the population. Dalori is located near one of the largest IDP camps in Nigeria with up to 25,000 internally displaced persons present. Boko Haram attacked the camp in the same attack as the raid against Dalori town but was repelled. ${ }^{117}$

Following the split, the JASDJ faction has not radically changed its tactics and has maintained its focus of attacks on civilians. This includes a particular focus on IDP camps. Mbiyozo notes that Boko Haram (although most likely JASDJ) launched 29 attacks on IDPs from 2015 to mid2017. ${ }^{118}$ The split between JASDJ and ISWAP did come however at a time of increased pressure on JASDJ from the Nigerian military which had launched a new and enhanced operation - 'Deep Punch' - to rout Boko Haram from its strongholds in the Sambisa forest, and this may have added an additional driver of attacks on civilians. Nasrullah has argued that this continued focus on civilian attacks has been designed to force Nigerian troops to disperse to protect towns and thus reduce pressure on JASDJ strongholds. Such tactics are certainly advocated by some of the jihadist strategists discussed above (and consistent with the strategic defence and strategic stalemate aspects of revolutionary warfare theory). ${ }^{119}$ It is, however, 
impossible to fully distinguish the tactical and doctrinal drivers of these attacks on civilians. In reality, they are probably mutually-supporting drivers of JASDJ's actions.

A recent assault on the town of Rann and its IDP camp in Borno state highlights the continued use of these tactics. Rann was attacked by the Shekau/JASDJ faction on Monday 14th January 2019 , with the military base and then the town being overrun. ${ }^{120}$ Rann was home to c.35,000 IDPs many of whom fled over the border to Cameroon. Satellite imagery analysed by Amnesty International shows extensive burning of the town in a model similar to the attack in Dalori. ${ }^{121}$ At the time of writing the exact number of victims is unknown but the Nigeria Security Tracker database quotes $60 .{ }^{122}$ This dual military/civilian attack is quite illustrative for JASDJ's recent tactics. Whether JASDJ is launching attacks on civilians to punish them or to disperse Nigerian forces (or, most likely, both), this characteristic of deliberate targeting of civilians runs counter to the revolutionary warfare approach and has alienated BH and then JASDJ from much of the population.

\section{Focusing on the Military? ISWAP Post-split}

Just as JASDJ has moved back and forth through the phases of guerrilla warfare outlined in revolutionary warfare theory (see above), following the 2016 split, ISWAP appeared to go into a period of retreat and consolidation (strategic defence). Under pressure from JASDJ and fearing an assault by the Nigerian military, the group relocated to North Borno on the borders of Lake Chad and consolidated its position. ${ }^{123}$ In line with its calls to avoid targeting the Muslim population, ISWAP has largely (but not entirely) eschewed attacks against civilians in Nigeria and, following a period of 'strategic defence' has increased and focused its attacks on the Nigerian military. According to ACLED ${ }^{124}$ data, between 1 August 2016 (the BH split was in August 2016) and the end of July 2018, ISWAP was involved in 20 battles with the Nigerian government. However, between August 2018 and the beginning of March 2019, ISWAP was involved in 84 battles with Nigerian state forces. By contrast, ACLED data records 6 instances of violence against civilians attributed to ISWAP in this latter time period (August 2018 until March 2019). For ISWAP that is a ratio of just over 14 recorded battles with the security forces for every one attack on civilians (despite clearly having the military capacity to attack civilians if they wished). For comparison, ACLED records 103 JASDJ battles with the Nigerian military and 49 attacks on civilians in the same time period. That is a ratio of just over two (2.10) battles for each attack on civilians. ${ }^{125}$

Following this resurgence of violence, the ISWAP-Nigerian military conflict appears to be entering a 'strategic stalemate' stage (in Maoist terms) or as being between the 'vexation and exhaustion' and 'management of savagery' phases as outlined by Naji. At the time of writing ISWAP appears to be having some localised semi-conventional successes against the Nigerian military, but not the power to permanently hold territory. Although there are instances, such as the case of an attack on the town of Metele in late 2018, where the group held territory for several days. ${ }^{126}$ Videos released by the group show extensive clashes with the military and document the capture of Nigerian bases via semi-conventional operations ${ }^{127}$. Recent ISWAP videos show effective manoeuvre attacks by BH fighters loaded into flatbed truck 'technicals' with mounted heavy machine guns. These technicals appear to be suppressing the troops in the attacked bases while dismounted 'infantry' attack the base and seek to breach the perimeter. The videos also show motorbike based RPG teams (with one fighter riding the motorcycle and another holding and then firing the rocket), dusk or dawn attacks with the use of tracer rounds and the use of up-armoured suicide vehicle-based improvised explosive devices (SBVIEDs ${ }^{128}$ ) used to attack bases. This is similar to the way that such weapons have been used by IS in Syria 
and Iraq. ${ }^{129}$ The combined effect of mounted technicals, dismounted fighters with small arms, RPG teams and suicide car bombs is a form of quite sophisticated, albeit semi-conventional, combined arms operations which have been successful in ousting Nigerian state forces from bases. These tactics are not fundamentally different from those of JASDJ (or other groups in the Sahel), although ISWAP attacks do appear to be more sophisticated, controlled and better executed than both recent JASDJ attacks ${ }^{130}$ and major JASDJ attacks in the past ${ }^{131}$. JASDJ does not appear to have used (as yet) the same up-armoured suicide vehicles that ISWAP has used, and ISWAP fighters seem better trained and with better weapons handling skills.

These operations appear to be having some localised success consistent with the "vexation and exhaustion' recommendations of Naji, forcing Nigerian forces to give up territory at times, and promoting reported instances of desertions of police and Army and insubordination. ${ }^{132}$ Analysis of quantitative battle data again (from the ACLED database) helps to highlight the military activity of ISWAP in the latter half of 2018 and early 2019 (before al-Barnawi was overthrown in late February/early March 2019). Between August 2018 and the beginning of March 2019 ACLED $^{133}$ records the largest number of battle-type events being armed clashes between ISWAP and the Nigerian military where no overall territory was lost either side (69 cases of a total of 84 battle events). While some of these were attacks on ISWAP by the Nigerian military, the majority of these clashes however were instigated by ISWAP. It should be noted as well that in a number of these cases ISWAP did take territory or bases temporarily only to relinquish them when faced with a reinforced counter attack. The second largest set of events are battles where ISWAP is thought of have seized territory from the Nigerian military (12 out of 84 cases). In three cases recorded by ACLED during this period, the Nigerian government (re)took territory from ISWAP ${ }^{134}$.

Reflecting the non-linear practice of proponents of revolutionary warfare, ISWAP seems, at the time of writing, to be quite prepared to give up captured military sites (and this is why it remains in the strategic stalemate phase in Maoist terms and largely the vexation and exhaustion phase in al-Naji's terms). Salkida argues that ISWAPs strategy is to continually be threatening and attacking Nigerian Forces in the north and central Borno (the areas it considers as part of its Caliphate) even if this means retreating when Nigerian forces return en masse. ${ }^{135}$ As long as they can keep Nigerian forces on the defensive, retreating from bases and losing weapons stocks, Salkida argues, ISWAP believes it will be easier to convince local populations that they are safer under ISWAP territory. He notes:

[I]n desisting from building visible administrative and military structures in the areas of their primary interest ISWAP have evolved in a way that is difficult for Nigerian troops to track. On the other hand, by being fixated with claim of control of territories, the military have only succeeded in making its troops sitting ducks and easy targets of the enemy. ${ }^{136}$

Nevertheless, reflecting the need to move up and down through the phases of warfare as outlined above, for the moment, ISWAP seems content to give up territory it controls without much of a fight. Al-Barnawi himself has been quite sanguine about this in the past. Reflecting the attritional and protracted nature of revolutionary warfare, in his 2016 al Naba' interview he notes "They [Nigerian forces] have seized some of the regions from us and we are working to get them back. We say to them that this should not be considered a victory, and that defeat is surrender and loss of will, and that we - praise to God - believe that it is a trial to purify the ranks." "137. Denying the Nigerian military control, capturing major weapons hauls from exposed troops and undermining government legitimacy seems to be the objective at present. ${ }^{138}$ This of 
course, alongside efforts to appeal to the local target population, is consistent with a longer term 'protracted' revolutionary warfare strategy.

\section{Conclusion}

This article has sought to use the concept of revolutionary warfare to assess the respective politico-military characters of the two main Boko Haram factions. As demonstrated above, the ISWAP faction demonstrates a military strategy that appears to be far more in line with the practice of revolutionary warfare than JASDJ. In conducting its own form of revolutionary warfare, ISWAP is extending doctrinal and strategic ideas that have existed on the peripheries of Boko Haram for some time. ISWAP under al-Barnawi however took them much further than other smaller factions, such as Ansaru. In so doing it reflects a position that is close to the forms of strategy advocated by Guevara, Giap, and Mao and shows similarities with the strategy advocated by Naji and other jihadist strategies. ISWAP appears to be operating somewhere in the 'strategic stalemate' phase in Maoist lexicon, targeting largely the Nigerian military with semi-conventional capabilities but only powerful enough to oust the Nigerian military temporarily from the territory. In Naji's phraseology, they are somewhere between the State of "vexation and exhaustion" and "the management of savagery" - although probably closer to the former.

The Shekau faction and Shekau-led BH before it, by contrast, have shown the capability to engage in semi-conventional war and seize significant territory (evidenced most notably by the establishment of their 'caliphate' in 2014-15), but with a military approach that remains heavily focused on civilian attacks. This approach is based almost exclusively on coercion (rather than the mix of coercion and co-optation seen in ISWAP's tactics) and largely rules out the possibility of a politically-based popular support strategy consistent with revolutionary warfare practice as defined by the Marxist and jihadist thinkers above. The group has been under far more military pressure in recent years, but this does not seem to have affected the military character of their strategy and the focus on civilians.

These differences are not set in stone and could change with time (especially given recent leadership changes in ISWAP), but they do mean that the ISWAP faction has opted for a mode of war that can be characterised as sharing an overall strategic approach with Marxist and jihadist revolutionary warfare approaches that emphasize the importance of developing population support. ISWAP's choice of a more revolutionary warfare approach suits their doctrinal position of limited takfir and their greater proclivity to take inspiration from abroad (especially from the Islamic State). While it is not a 'smoking gun', the reference to warfare strategies discussed by ISIS in al-Barnawi's al Naba' interview suggests he was aware of these ideas at least in 2016 although it is highly likely he and other ISWAP commanders were well aware of them before that. Barnawi was thus cognizant of how Shekau's position is strategically as well as doctrinally at odds with much wider jihadist thought. By contrast, Shekau's expansive view of al-wala wa-l-bara and takfir and more recent reported desire to reduce pressure on his forces by attacking civilians in an effort to spread the military thinly directly contradicts a revolutionary approach that must win over the (neutral) population. ISWAPs more open approach towards the wider civilian population is also in no small part a response to JASDJ violence - as evidenced by ISWAP's denunciations of Shekau. ISWAP has deliberately tried hard to present itself as a supporter of the population to distance themselves from JASDJ violence and thus potentially generate support contra the Shekau faction as well as the government. 
This has bearing on the response of the Nigerian Government. Firstly, from a strictly military perspective, it creates a dilemma in terms of targeting both groups. The revolutionary approach of ISWAP may present the bigger long-term threat to Nigerian sovereignty and the Nigerian military directly, while the Shekau faction presents a bigger direct threat to civilians in Nigeria and the neighbouring countries ${ }^{139}$. It is yet to be seen whether the population centricity of ISWAP will make them a more formidable threat over the long term, but history would suggest this poses considerable risks (and this is an important field for further enquiry). The ISWAP faction appears (at least for now) to be the biggest military threat and efforts must be directed to fully equipping and preparing soldiers (especially those most exposed to the types of attacks and raids described above). Secondly, and more broadly, the 'population centric' nature of ISWAP draws attention to the extremely difficult conditions facing some communities in North East Nigeria - including for the many now housed in IDP camps. It is imperative that the Nigerian government refrain from undertaking activities that would support ISWAP's narratives and allow the group to present themselves as being on the side of the 'people' contra the government and local authorities. This of course includes human rights abuses perpetrated by the state, but also requires very careful consideration of any restrictions on economic activity and civil liberties that could weaken human security and may drive recruits to, or increase sympathy for, ISWAP. History tells us that the 'human terrain' is at least as important as (if not more important than) the military dimension in (counter) revolutionary warfare. Many civilians are caught in the middle and require support from their government, even if they have engaged with the militants. There is a critical need therefore, from both an ethical and strategic standpoint, to address the grievances and social injustices that may make ISWAP's narratives attractive and to place the security dilemma for affected communities at the heart of counter insurgency actions.

Given the connections drawn between Marxist and Jihadist strategic practice, this study also has further significance for the literature on jihadist militancy. The key finding of this study that even two factions originating from the same jihadist movement practice insurgency quite differently - highlights the variation in jihadist strategic practice. While jihadist strategists and both 'Islamic State' and al-Qaeda have proffered strategic views based on revolutionary warfare principles, further research into the extent to which this practice extends to 'affiliates' and 'provinces' would further strategic understanding of the overlap and divergence between jihadist groups. ISWAP follows an insurgency model that is close to the Islamic State's own stated view, but it does so in part because of its local tensions with JASDJ and the nature of its competition with the Nigerian state. Future comparative research into jihadist revolutionary military practice would thus be welcome to further knowledge of the global and local drivers of strategic practice in the wider transnational jihadist-salafist movement.

\section{Disclosure statement}

No potential conflict of interest was reported by the author.

\section{Notes}

1 Freedom C. Onuoha, "Split in ISIS-Aligned Boko Haram Group," last modified October 27, 2016 http://studies.aljazeera.net/en/reports/2016/10/split-isis-aligned-boko-haram-group-161027113247008.html (accessed Feburary 03, 2019).

${ }^{2}$ At the time of writing there is still minimal public information available about the overthrow of al-Barnawi and his replacement by new leader Abu Abdullah Ibn Umar al-barnawi. See Ahmed Salkida, Islamic State 
'Sacks' Al-Barnawi As ISWAP Leader, last modified March 04, 2019, http://saharareporters.com/2019/03/04/breaking-islamic-state-\%E2\%80\%98sacks\%E2\%80\%99-al-barnawiiswap-leader, (Accessed March 20th, 2019). The demise of al-Barnawi as leader provides the finishing point for the analysis here (up to the beginning of March 2019). There appears however to be no radical departure in terms of approach and relations with the population under the new leader (See for example Obi Anyadike, Reporter's Diary: Boko Haram and the Battle of Ideas, last modified $6^{\text {th }}$ August 2019, https://www.thenewhumanitarian.org/analysis/2019/08/06/Nigeria-boko-haram-ISWAP-and-battle-ideas-LakeChad [accessed 12, August 2019]). Nevertheless, a full analysis of ISWAP under the new leadership is beyond the scope of this paper.

${ }^{3}$ Abdulbasit Kassim, "Defining and Understanding the Religious Philosophy of Jihādī-Salafism and the Ideology of Boko Haram," Politics, Religion \& Ideology 16, no. 2-3 (2015): 173-200; Iro Aghedo, "Old Wine in a New Bottle," in Understanding Boko Haram: Terrorism and Insurgency in Africa, ed. James Hentz and Hussein Solomon (London: Routledge, 2017), 65; Jacob Zenn and Zacharias Pieri, "How Much Takfir is Too Much Takfir? The Evolution of Boko Haram's Factionalization." Journal for Deradicalization 11, no. 3 (2017): 281-308; Abdulbasit Kassim and Michael Nwankpa. The Boko Haram Reader: From Nigerian Preachers to the Islamic State. (Oxford: Oxford University Press, 2018).

4 Alexander Thurston, Boko Haram: The History of an African Jihadist Movement (Princeton: Princeton University Press, 2017); Olabanji Akinola, "Boko Haram insurgency in Nigeria: Between Islamic Fundamentalism, Politics, and Poverty," African Security 8, no. 1 (2015): 1-29; Andrew Walker, 'Eat the Heart of the Infidel': the Harrowing of Nigeria and the Rise of Boko Haram. (London: Hurst, 2016); Hilary Matfess, "Boko Haram: History and Context," http://oxfordre.com/africanhistory/view/10.1093/acrefore/9780190277734.001.0001/acrefore-9780190277734e-119?print=pdf (accessed March 04, 2019).

${ }_{5}^{5}$ John A. Stevenson, Amy Pate, and Elvis Asiamah, "Effective Counter-Terrorism Against Boko Haram: Empirical Assessments of Coercion, Delegitimization, Incentivization and Denial Strategies in Nigeria (20092014)." in Understanding Boko Haram: Terrorism and Insurgency in Africa, ed. James Hentz and Hussein Solomon (London: Routledge, 2017), 188-217; Isaac Olawale Albert, "Rethinking the functionality of the Multinational Joint Task Force in managing the Boko Haram crisis in the Lake Chad Basin." Africa Development 42, no. 3 (2017): 119-135.Kwesi Aning, Mustapha Abdallah, and Festus Kofi Aubyn. "Responding to Boko Haram: Interrogating the Effectiveness of State and Regional Intervention Approaches." in Understanding Boko Haram: Terrorism and Insurgency in Africa, ed. James Hentz and Hussein Solomon (London: Routledge, 2017), 237-253; Virginia Comolli, Boko Haram: Nigeria's Islamist Insurgency (Oxford: Oxford University Press, 2015).

${ }^{6}$ Abdulbasit Kassim, "Boko Haram's Internal Civil war: Stealth Takfir and Jihad as Recipes for Schism." in Boko Haram Beyond the Headlines: Analyses of Africa's Enduring Insurgency, ed. Jacob Zenn (New York: West Point CTC, 2018); Zenn and Pieri, "How much Takfir is too much Takfir?"

${ }^{7}$ For exceptions see Akali Omeni, "Boko Haram's increasingly sophisticated military threat," Small Wars \& Insurgencies 29, no. 5-6 (2018): 886-915.Omar S. Mahmood and Ndubuisi Christian Ani, "Factional Dynamics within Boko Haram" (Institute for Security Studies Research Report, July 2018),

https://issafrica.s3.amazonaws.com/site/uploads/2018-07-06-research-report-2.pdf , (accessed January 21, 2019); Daniel Törbjornsson and Michael Jonsson, "Boko Haram. On the Verge of Defeat or a Long Term Threat?" (Totalförsvarets Forskningsinstitut, 2017) https://www.foi.se/rapportsammanfattning?reportNo=FOIR--4488--SE (accessed January 21, 2019).

${ }^{8}$ Matfess, "Boko Haram: History and Context"

9 Marc Hecker, "De Marighella à Ben Laden," Politique Étrangère vol. Été, no. 2 (2006): 385-396; John Mackinlay, The Insurgent Archipelago: from Mao to Bin Laden. (New York: Columbia University Press, 2009); Michael WS. Ryan, "ISIS: The Terrorist Group That Would Be a State" (Center on Irregular Warfare \& Armed Groups (CIWAG), US Naval War College, 2015); Stathis Kalyvas, "Is ISIS a Revolutionary Group and if Yes, What are the Implications?" Perspectives on Terrorism 9, no. 4 (2015): 42-47; Stathis Kalyvas, "Jihadi Rebels in Civil War," Daedalus 147, no. 1 (2018): 36-47; Craig Whiteside, "New Masters of Revolutionary Warfare: The Islamic State Movement (2002-2016)," Perspectives on Terrorism 10, no. 4 (2016): 4-18; Craig Whiteside, "The Islamic State and the Return of Revolutionary Warfare," Small Wars \& Insurgencies 27, no. 5 (2016): 743-776; Stephen M. Walt, "ISIS as Revolutionary State." Foreign Affairs 94 (2015): 42.

10 Laia Balcells and Stathis N. Kalyvas, "Revolutionary Rebels and the Marxist Paradox," (2015), 1. http://cpd.berkeley.edu/wp-content/uploads/2015/04/MarxIns_4_15.pdf (accessed February 12, 2019).

11 Hassan Hassan, "Sunni Jihad Is Going Local," last modified February 15, 2019, https://www.theatlantic.com/ideas/archive/2019/02/sunni-jihad-turns-away-transnational-terrorism/582745/, (accessed February 17, 2019); Michael WS. Ryan, "ISIS: The Terrorist Group That Would Be a State", 21.

${ }^{12}$ Hew Strachan and Sibylle Scheipers, "Introduction: The Changing Character of War", ed. Hew Strachan and Sibylle Scheipers, The Changing Character of War (Oxford: Oxford University Press, 2011). 
${ }^{13}$ On this difference Strachan and Scheipers note that there is a "distinction between the nature of war, which has an essential continuity, even integrity, and the character of individual wars, which vary". The key point here is that there are certain immutable features of war (such as violence, change etc.) but that the actual conduct and characteristics of war change over time. Furthermore, change need not mean novelty or 'newness', but rather a return to actions of the past. Ibid, 11.

${ }^{14}$ Ibid, 4.

15 Ibid.

16 Julia Lovell and Laurie Taylor, "Maoism", Thinking Allowed Podcast, last modified November 26, 2019 , https://www.bbc.co.uk/programmes/m000179n, (Accessed December 10, 2019).

17 Mackinlay, The Insurgent Archipelago; Hecker, "De Marighella à Ben Laden,"; Kalyvas, "Is ISIS a Revolutionary group and if Yes, What are the Implications?", 42-47; Kalyvas, "Jihadi Rebels in Civil War,", 3647.; Whiteside, "New masters of revolutionary warfare: The Islamic State movement (2002-2016)"; Whiteside, "The Islamic State and the return of revolutionary warfare"; Walt, "ISIS as Revolutionary State." 42; Rich, "How Revolutionary are Jihadist Insurgencies? The Case of ISIL," Small Wars \& Insurgencies 27, no. 5 (2016): 777799; Thomas Hegghammer, "Jihadi-Salafis or Revolutionaries? On Religion and Politics in the Study of Militant Islamism." in Global Salafism: Islam's New Religious Movement, ed. Roel Meijer, (New York: Columbia, 2009): 244-266.

${ }^{18}$ Although not entirely impossible. See Omeni, "Boko Haram's increasingly sophisticated military threat,".

${ }^{19}$ Kassim and 1 Nwankpa. The Boko Haram Reader: From Nigerian Preachers to the Islamic State.

${ }^{20}$ Some may question the reliability of relying on datasets based on media reports. The author contacted

ACLED regarding the coding of different actors and they outlined the process used to ensure (as much as is possible) the accuracy of this data. This paper however uses the quantitative data to support the general arguments made (in that sense it is a further point of triangulation along with the qualitative data) rather than the sole research basis for the article's arguments. Generally, the statistical findings are in line with the qualitative findings below.

${ }^{21}$ Robert Taber, War of the Flea: The Classic Study of Guerrilla Warfare (Dulles: Potomac Books, 2002);

Max. Boot, Invisible Armies: An Epic History of Guerrilla Warfare from Ancient Times to the Present. (New York: WW Norton \& Company, 2013), 346.

${ }^{22}$ Craig, Whiteside, "The Islamic State and the Return of Revolutionary Warfare." Small Wars \& Insurgencies

27, no. 5 (2016): 743-776; see also Bernard Fall, "The Theory and Practice of Insurgency and Counterinsurgency." Naval War College Review 18, no. 3 (1965): 21-37.

${ }^{23}$ Lawrence Freedman, Strategy: A History. (Oxford: Oxford University Press, 2015), 183-186.

${ }^{24}$ Stuart Lyle, "Maoism versus "Hybrid" theory - Is the military being distracted by this latest doctrinal buzzword?" (2011), 2. http://www.ukdf.org.uk/assets/downloads/111201MaoismversusHybridtheory.pdf (accessed January 07, 2019)

${ }^{25}$ Chalmers Johnson, "The Third Generation of Guerrilla Warfare," Asian Survey 8, no. 6 (1968): 435-447; John Ellis, Armies in revolution. (Abingdon: Taylor \& Francis, 1973), 213.

${ }^{26}$ Craig Whiteside, "New masters of revolutionary warfare: The Islamic State movement (2002-2016)." 4-18; Craig Whiteside, "The Islamic State and the Return of Revolutionary Warfare." 743-776.

${ }^{27}$ Hecker, "De Marighella à Ben Laden".

${ }^{28}$ Kalyvas, "Is ISIS a Revolutionary group and if Yes, What are the Implications?" 42-47; Walt, "ISIS as Revolutionary State." 42.

${ }^{29}$ Kalyvas, "Jihadi Rebels in Civil War," 42-44.

${ }^{30}$ Kenneth Payne, "Building the Base: Al Qaeda's Focoist Strategy,” Studies in Conflict \& Terrorism 34, no. 2 (2011): 128.

31 'Abd Al' Aziz Al-Muqrin, Al-Qa'ida's Doctrine of Insurgency: 'Abd Al'Aziz Al-Muqrin's A Practical Course for Guerilla War, trans N. Cigar, (Washington: Potomac Books, 2009); George Michael, "A Review of: "Norman Cigar. Al-Qa'ida's Doctrine of Insurgency: 'Abd Al' Aziz Al-Muqrin's A Practical Course for Guerilla War," Terrorism and Political Violence 22, no.1 (2009): 125.

32 Kenneth Payne, "Building the Base: Al Qaeda's Focoist Strategy"; Al-Muqrin, Al-Qa'ida's Doctrine of Insurgency, 12; Daveed Gartenstein-Ross, Nathaniel Barr, Bridget Moreng and Jason Fritz, "Islamic State Versus Al Qaeda: Strategic Dimensions of a Patricidal Conflict", (New America International Security Program Report, 2015) available at: https://static.newamerica.org/attachments/12103-islamic-state-vs-alqaeda/ISISvAQ_Final.e68fdd22a90e49c4af1d4cd0dc9e3651.pdf, (Accessed, March 20th, 2019).

33 Alexander Thurston, 'Abū Muṣ'ab al-Barnāwī’s Interview with the Islamic State's Al-Naba' Magazine', Journal for Islamic Studies 36, (2017): Footnote 28.

${ }^{34}$ Doris M. Condit, Modern Revolutionary Warfare: An Analytical Overview (Washington: American Institutes for Research Kensington MD, 1973): vi.

${ }^{35}$ Stathis N. Kalyvas, "Is ISIS a Revolutionary group and if Yes, What are the Implications?" 43.

${ }^{36}$ Al-Qurashi quoted in Michael WS. Ryan, "ISIS: The Terrorist Group That Would Be a State" 21. 
${ }^{37}$ Stathis N. Kalyvas, "Is ISIS a Revolutionary group and if Yes, What are the Implications?" 44.

${ }^{38}$ John Mackinlay, The Insurgent Archipelago: from Mao to bin Laden, 17.

${ }^{39}$ Mao Tse Tung, Mao Tse-Tung On Guerilla Warfare, trans C. Griffith,

https://www.marines.mil/Portals/1/Publications/FMFRP\%2012-18\%20\%20Mao\%20Tse-

tung\%20on\%20Guerrilla\%20Warfare.pdf, (Accessed August 13 ${ }^{\text {th }}, 2019$ ), 93.

${ }^{40}$ Ibid. 92

${ }^{41}$ Kenneth Payne, "Building the Base: Al Qaeda's Focoist Strategy," 124.

${ }^{42}$ Ibid. 125. Ernesto Che Guevara, Guerilla Warfare: A Method. (Peking: Foreign Language Press, 1964), 2.

${ }^{43}$ Ibid.

${ }^{44}$ Abu Bakr Al Naji, Management of Savagery; The Final Stage Through Which the Umma Will Pass, trans W. McCants.

${ }^{45}$ Ibid. 48

${ }^{46} \mathrm{Ibid}$.

${ }^{47}$ Max Boot, Invisible Armies: An Epic History of Guerrilla Warfare from Ancient Times to the Present, 332.

${ }^{48}$ Shiraz Maher, Salafi-Jihadism: The History of an Idea. (Oxford: Oxford University Press, 2016), 104.

${ }^{49}$ Stuart Lyle, "Maoism versus "Hybrid" theory - Is the Military Being Distracted by this Latest Doctrinal Buzzword?" (2011), 2. http://www.ukdf.org.uk/assets/downloads/111201MaoismversusHybridtheory.pdf (accessed February 10, 2019); Robert B. Asprey, "War in the Shadows: The Guerilla in History, Vol 1. (Garden City, New York: Douleday \& Company, 1975), 388 \& 748; John Ellis, Armies in Revolution, 218-224; Doris M. Condit, Modern Revolutionary Warfare: An Analytical Overview, vi; Lawrence Freedman, Strategy: A history, 183-186.

${ }^{50}$ Robert B. Asprey, "War in the Shadows: The Guerilla in History, Vol 1, 388; Stuart Lyle, "Maoism Versus "Hybrid" Theory".

${ }^{51}$ Thurston, “Abū Muṣ'ab al-Barnāwī’s Interview with the Islamic State's Al-Naba' Magazine”, fn28.

${ }^{52} \mathrm{Al}$ Naji, Management of Savagery, 16-17.

${ }^{53}$ Ibid.17-18.

${ }^{54}$ Jarret M. Brachman and William F. McCants, "Stealing Al Qaeda's Playbook," Studies in Conflict \& Terrorism 29, no. 4 (2006): 311.

${ }^{55}$ George Michael, "A Review of: "Norman Cigar. Al-Qa'ida's Doctrine of Insurgency: 'Abd Al'Aziz Al-Muqrin's A Practical Course for Guerilla War," Terrorism and Political Violence 22, no.1 (2009): 125.

${ }^{56}$ Lawrence Freedman, Strategy: A History, 186.

${ }^{57}$ Abdulbasit Kassim, "Boko Haram's Internal Civil War: Stealth Takfir and Jihad as Recipes for Schism." 2122.

${ }^{58}$ Lawrence Freedman, Strategy: A History, 188.

${ }^{59}$ Quintan Wiktorowicz, "Anatomy of the Salafi movement", Studies in Conflict \& Terrorism 29, no. 3 (2006): 221.

${ }^{60}$ Marc-Antoine Pérouse de Montclos, "Boko Haram: A Jihadist Enigma in Nigeria," in Understanding Boko Haram: Terrorism and Insurgency in Africa, ed. James Hentz and Hussein Solomon (London: Routledge, 2017), 27.

${ }^{61}$ Marc-Antoine Pérouse de Montclos, "Boko Haram: a Jihadist Enigma in Nigeria," 26; Abdulbasit Kassim, "Defining and Understanding the Religious Philosophy of jihādī-Salafism and the Ideology of Boko Haram,"198; Jacob Zenn and Zacharias Pieri, "How much Takfir is too much Takfir? The Evolution of Boko Haram's Factionalization," 47.

${ }^{62}$ Abdulbasit Kassim, "Defining and Understanding the Religious Philosophy of Jihādī-Salafism and the Ideology of Boko Haram,"188.

${ }^{63}$ Ibid. 189.

${ }^{64}$ Kyari Mohammed, "The message and methods of Boko Haram." in Boko Haram: Islamism, politics, security and the state in Nigeria, ed Marc-Antoine Pérouse de Montclos (Leiden: African Studies Centre 2014): 9-32.

${ }^{65}$ Shiraz Maher, Salafi-Jihadism: The history of an idea, 90.

${ }^{66}$ Abdulbasit Kassim, "Defining and Understanding the Religious Philosophy of Jihādī-Salafism and the Ideology of Boko Haram," 191.

67 Alexander Thurston, "Boko Haram and Religious Exclusivism", OUP Blog, April, 14, 2015 https://blog.oup.com/2015/04/boko-haram-religious-exclusivism/ (accessed March 01, 2019).

${ }^{68}$ Shekau quoted in Abdulbasit Kassim, "Defining and Understanding the Religious Philosophy of Jihādī-Salafism and the Ideology of Boko Haram,"192.

${ }^{69}$ Alexander Thurston, "Boko Haram and Religious Exclusivism".

${ }^{70}$ Thurston, Boko Haram: The History of an African Jihadist Movement, 217.

${ }^{71}$ Ibid.

72 John Campbell and Asch Harwood, "Boko Haram's Deadly Impact," last modified August 20, 2018, https://www.cfr.org/article/boko-harams-deadly-impact (accessed March 07, 2019) 
${ }^{73}$ Abu Musab al Barnawi, "Interview with Official Spokesman Abu Musab Al Barnawi About the Events in the City of Baga" trans. Abdulbassit Kassim, in The Boko Haram Reader: From Nigerian Preachers to the Islamic State ed. Abdulbasit Kassim, Micheal Nwankpa and David Cook (Oxford: Oxford University Press, 2018). 371. ${ }^{74}$ Ibid.

${ }^{75}$ Abu Bakar al Shekau, "Message to the World on Baga" trans. Abdulbassit Kassim, in The Boko Haram Reader: From Nigerian Preachers to the Islamic State ed. Abdulbasit Kassim, Micheal Nwankpa and David Cook (Oxford: Oxford University Press, 2018). 365.

${ }^{76}$ Abu Musab al Barnawi, "Interview with Official Spokesman Abu Musab Al Barnawi About the Events in the City of Baga", 371.

77 Abu Bakar Shekau, "Message to the World by Abubakar Shekau", trans. Abdulbassit Kassim, in The Boko Haram Reader: From Nigerian Preachers to the Islamic State ed. Abdulbasit Kassim, Micheal Nwankpa and David Cook (Oxford: Oxford University Press, 2018). 263. Shekau's framing of Boko Haram as a defender of the Islamic faith is well documented in Oriola, Temitope B., and Olabanji Akinola. "Ideational dimensions of the Boko Haram phenomenon." Studies in Conflict \& Terrorism 41, no. 8 (2018):601-602, 605.

78 Jamat Ansar Al Muslimin, "Dissasociation of Jamat Ansar Al Muslimin from Targetting Muslim Innocents" trans. David Cook, in The Boko Haram Reader: From Nigerian Preachers to the Islamic State ed. Abdulbasit Kassim, Micheal Nwankpa and David Cook (Oxford: Oxford University Press, 2018). 277.

${ }^{79}$ Ibid.

${ }^{80}$ Abu Musab al Barnawi, Cutting Out the Tumour from the Khawarij of Shekau by the Allegiance Pledge of the People of Nobility, trans A.J. Al-Tamimi, available online at: http://www.aymennjawad.org/21467/the-islamicstate-west-africa-province-vs-abu.

${ }^{81}$ Abdulbasit Kassim, Micheal Nwankpa and David Cook make this point. See introduction to Abu Musab al Barnawi, "Interview with Official Spokesman Abu Musab Al Barnawi About the Events in the City of Baga" trans. Abdulbassit Kassim, in The Boko Haram Reader: From Nigerian Preachers to the Islamic State ed. Abdulbasit Kassim, Micheal Nwankpa and David Cook (Oxford: Oxford University Press, 2018). 369.

${ }^{82}$ Ibid, 371.

83 Jamat Ansar Al Muslimin, "Dissasociation of Jamat Ansar Al Muslimin from Targetting Muslim Innocents", 276.

${ }^{84}$ Abu Musab al Barnawi, Cutting Out the Tumour.

85 Ibid.

${ }^{86}$ Paul Carsten and Ahmed Kingimi, "Islamic State Ally Stakes Out Territory Around Lake Chad," last modified April 29, 2018, https://www.thestar.com.my/news/world/2018/04/29/islamic-state-ally-stakes-out-territoryaround-lake-chad/\#VUAZTH1igx2G1s8Z.99 (accessed March 01, 2019)

87 Deutsche Welle (2018) https://www.dw.com/en/boko-haram-islamists-still-control-parts-of-northeasternnigeria/a-43851013 (accessed March 01, 2019).

${ }^{88}$ Idiyat Hassan, “OPINION: The Dangers of a Better Behaved Boko Haram”, last modified August 21, 2018, https://www.thenewhumanitarian.org/opinion/2018/08/21/opinion-nigeria-militancy-peace-boko-haram, (accessed February 17, 2019).

${ }^{89}$ Carsten and Kingimi, "Islamic State ally stakes out territory around Lake Chad".

${ }^{90}$ Mahmood and Christian Ani." Factional Dynamics within Boko Haram".

${ }^{91}$ Hassan, "OPINION: The Dangers of a Better Behaved Boko Haram".

92 BBC, 'Islamic State-linked militants 'seize Nigeria's Baga town', last modified December 28, 2018, https://www.bbc.com/news/world-africa-46705837, (accessed January 05, 2019).

${ }^{93}$ France24, “Au Nigeria, la Spectaculaire Remontée en Puissance de Boko Haram”, last modified January 05, 2019, https://www.france24.com/fr/20190105-afrique-nigeria-remontee-puissance-boko-haram-iswap-attaquesjihadistes-ei, (accessed January 10, 2019).

${ }_{94}$ Mahmood and Christian Ani. "Factional Dynamics within Boko Haram", 27.

95 Ibid.

${ }^{96}$ Ibid.

${ }^{97}$ Ahmad Salkida, “SPECIAL REPORT: Why Troops Are Losing Ground To ISWAP," last modified January 2 , 2019, http://saharareporters.com/2019/01/02/special-report-why-troops-are-losing-ground-iswap, (accessed January 03, 2019)

${ }_{98}^{98}$ Mahmood and Christian Ani." Factional Dynamics within Boko Haram," 27.

${ }^{99}$ Ibid.

${ }^{100}$ David Kilcullen, Out of the Mountains: The Coming Age of the Urban Guerrilla. (Oxford: Oxford University Press, 2015).

${ }^{101}$ Aaron Zelin, "New Video Message from the Islamic State - Blessings and Tribulations 'Wilayat Gharb Ifriqiyya"”, last modified July 11 2018, https://jihadology.net/2018/07/11/new-video-message-from-the-islamicstate-tribulations-and-blessings-wilayat-gharb-ifriqiyyah/, (Accessed March 24th, 2019), (03:55 onwards). 
102 BBC, Dapchi girls: Freed Nigerian Girls Tell of Kidnap Ordeal, last modified 22 March 2018, https://www.bbc.co.uk/news/43489217 (Accessed August 12th, 2019).

103 The author has reviewed the video which is widely thought to be of the release. It does not show the girls being released however, but rather a local crowd surrounding and engaging with the militants. It is difficult to geo-locate to Dapchi with $100 \%$ confidence because the footage is grainy/wobbly and landmarks are not easy to locate with full confidence through satellite imagery. However, based on identifiable landmarks, the author would assess with medium confidence that it is Dapchi as claimed in the video (coordinates in the vicinity of 12.497758, 11.504678). The video can be found here: https://www.youtube.com/watch?v=WqMuA6OCw8g. ${ }^{104}$ International Crisis Group, Facing the Challenge of the Islamic State in West Africa Province, Report No. 273/Africa, https://www.crisisgroup.org/africa/west-africa/nigeria/273-facing-challenge-islamic-state-westafrica-province, (Accessed August 14, 2019).

${ }^{105}$ Chitra Nagarajan, Twitter thread, July $27^{\text {th }} 2019,12: 00 \mathrm{pm}$,

https://twitter.com/chitranagarajan/status/1155195643465523201

${ }^{106}$ Obi Anyadike, “Reporter's Diary and the Battle for Ideas", last modified August 6, 2019, https://www.thenewhumanitarian.org/analysis/2019/08/06/Nigeria-boko-haram-ISWAP-and-battle-ideas-LakeChad, (Accessed August 14, 2019).

${ }^{107}$ Kingsly Nwezeh, MNJTF Raises Alarm on ISWAP's Recruitment Plans, last modified June 12, 2019 , https://www.pressreader.com/nigeria/thisday/20190612/281930249489582, (Accessed August 14, 2019).

108 Omar S. Mahmood and Ndubuisi Christian Ani." Factional Dynamics within Boko Haram," 28. 109 Hilary Matfess, "Boko Haram: History and Context," http://oxfordre.com/africanhistory/view/10.1093/acrefore/9780190277734.001.0001/acrefore-9780190277734e-119?print=pdf (accessed March 04, 2019).

110 Rick Burns, Threat Tactics Report: Boko Haram, last modified October, 2015, https://info.publicintelligence.net/USArmy-BokoHaram.pdf, (Accessed March 23rd, 2019), 7-8.

${ }^{111}$ Sam Jones and Monica Mark, Boko Haram: satellite images reveal devastation of massacre in Nigeria, last modified, January 15th, 2015 https://www.theguardian.com/world/2015/jan/14/satellite-images-revealdevastation-boko-haram-massacre-nigeria, (Accessed March 24th, 2019).

${ }^{112}$ Fred Lambert, "Nigerian General Jailed for Failing to Stop Boko Haram Raid," last modified October 18, 2015, https://www.upi.com/Top_News/World-News/2015/10/18/Nigerian-general-jailed-for-failing-to-stop-BokoHaram-raid/5021445216634/ (accessed January 05, 2019).

${ }_{113}$ Monica Mark, "Boko Haram's 'Deadliest Massacre': 2,000 Feared Dead in Nigeria,” last modified January 10, 2015, https://www.theguardian.com/world/2015/jan/09/boko-haram-deadliest-massacre-baga-nigeria (accessed February 04, 2019).

${ }^{114}$ In addition to events coded as 'violence against civilians', this also includes events coded in the ACLED database as 'Explosions/Remote violence' where civilians were the targets and a number of 'strategic developments' that also targeted civilians.

${ }^{115}$ Raleigh, Clionadh, Andrew Linke, Hvard Hegre, and Joakim Karlsen. "Introducing ACLED: An Armed Conflict Location and Event Data." Journal of Peace Research 47, no. 5 (2010): 651-660. Data set available at https://www.acleddata.com/.

${ }^{116}$ Guardian, "Boko Haram: children among villagers burned to death in Nigeria attack", last modified February 01, 2016, https://www.theguardian.com/world/2016/feb/01/boko-haram-attack-children-among-villagersburned-to-death-in-nigeria, (accessed February 04, 2019).

117 Ibid.

118 Aimée-Noël Mbiyozo, "Policy Brief. How Boko Haram Specifically Targets Displaced People," (Institute for Security Studies, 2017), https://reliefweb.int/sites/reliefweb.int/files/resources/policybrief109.pdf, (accessed February 04, 2019).

${ }^{119}$ Fulan Nasrullah, "Strategic Thinking Behind Ongoing Insurgent Offensive Operations In Northeast NigeriaAn Analysis," last modified August 4, 2018, https://studiesandanalysis.wordpress.com/2018/08/04/strategicthinking-behind-ongoing-insurgent-offensive-operations-in-northeast-nigeria-an-analysis/ (accessed March 04, 2019).

${ }^{120}$ Fergus Kelly, "Shekau Boko Haram Faction Claims Attack in Rann, Nigeria”, last modified January 17, 2019 https://thedefensepost.com/2019/01/17/nigeria-boko-haram-shekau-faction-claims-rann-attack-video/, (accessed January 20, 2019).

121 Amnesty International (2019) https://www.amnesty.org/en/latest/news/2019/02/nigeria-deadliest-bokoharam-attack-on-rann-leaves-at-least-60-people-murdered/ (accessed March 04, 2019).

${ }_{122}$ Ralph Buncke and John Campbell, "Nigeria Security Tracker Database", Council of Foreign Relations, https://www.cfr.org/nigeria/nigeria-security-tracker/p29483.

${ }^{123}$ Nasrullah, "Strategic Thinking Behind Ongoing Insurgent Offensive Operations in Northeast Nigeria". 
${ }^{124}$ Raleigh, Clionadh, Andrew Linke, Hvard Hegre, and Joakim Karlsen. "Introducing ACLED: An Armed Conflict Location and Event Data".

${ }^{125}$ As noted above, it is possible that some of these are miscoded adding to the perception of more attacks against civilians by JASDJ. However, as the ratios are so different (14:1 and 2:1), it is unlikely that some miscoded entries would undermine the argument. The fact that this finding reinforces the other findings adds further weight to the statistics.

${ }^{126}$ Nasrullah, "Strategic Thinking Behind Ongoing Insurgent Offensive Operations in Northeast Nigeria".

${ }^{127}$ Aaron Zelin, "New Video Message from the Islamic State - Blessings and Tribulations 'Wilayat Gharb Ifriqiyya",.

${ }^{128}$ Ibid, 07:11.

${ }^{129}$ Margaret Coker, "How Islamic State's Win in Ramadi Reveals New Weapons, Tactical Sophistication and Prowess," last modified May 25, 2015, https://www.wsj.com/articles/islamic-states-gains-reveal-new-prowesson-battlefield-1432592298 (accessed March, 03, 2019); David, Kilcullen, Blood year: The unraveling of Western counterterrorism. (Oxford: Oxford University Press, 2016), 142.

${ }^{130}$ Aaron Zelin, "New Video Message from Jamaat Ahl al-Sunna li-l-Da'wah wa-l-Jihad: Victory Comes Only From God \#5". (2018)

${ }^{131}$ Aaron Zelin, "New Message from Boko Haram (Jamaat Ahl al-Sunna li-1-Da'wah wa-l-Jihad): The Raid of Maiduguri\#2. (2014)

132 Samuel Ogundipe, "Boko Haram: Despite evidence, Nigerian police deny 167 officers absconded," last modified December 26, 2018, https://www.premiumtimesng.com/news/headlines/302923-boko-haram-despiteevidence-nigerian-police-deny-167-officers-absconded.html (accessed March 03, 2019); Jude Egbas, "Here's why soldiers shot inside Maiduguri airport," last modified August 13, 2018, https://www.pulse.ng/news/local/boko-haram-heres-why-soldiers-shot-inside-maiduguri-airport/42ynzbc (accessed March 04, 2019).

${ }^{133}$ Raleigh, Clionadh, Andrew Linke, Hvard Hegre, and Joakim Karlsen. "Introducing ACLED: An Armed Conflict Location and Event Data".

${ }^{134}$ Given the difficulties of collecting this sort of data, it is possible that some instances are not recorded. Nevertheless, it shows the significant challenge posed by ISWAP during this period. It should be noted that in the period following al-Barnawi's removal, ISWAP has come under some increased pressure in Northern Nigeria, including from Chadian forces. At the time of writing however there has been no dramatic reversal in the overall picture, even if ISWAP have suffered some heavy losses in a number of instances.

${ }^{135}$ Ahmad Salkida, "SPECIAL REPORT".

136 Ibid.

${ }^{137}$ Thurston, “Abū Muș'ab al-Barnāw̄̄’s Interview with the Islamic State’s Al-Naba' Magazine”. 138 Ahmad Salkida, "SPECIAL REPORT".

139 Hassan, “OPINION: The Dangers of a Better Behaved Boko Haram"; Jacob Zenn, "Boko Haram's Factional Feuds: Internal Extremism and External Interventions", Terrorism and Political Violence, (2019):

DOI:10.1080/09546553.2019.1566127: 22. 